\title{
Attitude of Responsibility of Prospective Counselors in Utilizing Internet Technology
}

\author{
Nova Erlina Yaumas, Syafrimen Syafril \\ Universitas Islam Negeri Raden Intan Lampung \\ syafrimen@radenintan.ac.id
}

Submitted: 2019-08-21, Revised: 2019-09-14, Accepted: 2019-11-07

\begin{abstract}
Students in the Department of Guidance and counseling are prospective education counselors who need to be given information about the use of internet technology that is good and right. The attitude of student responsibility needs to be known by educators so that educators can provide services to instill the attitude of student responsibility in the use of internet technology. This study aims to see the responsible attitude of prospective counselors in the use of internet technology in students of Guidance and Counseling. Research conducted through a qualitative approach, which refers to the case study research design. Potential Guidance and Counseling teachers who are also prospective counselors at the Faculty of Tarbiyah and teacher training at UIN Raden Intan Lampung became the subject of research. The research data were analyzed in a descriptive thematic way using Nvivo software. The results showed that there were still students who were not responsible for utilizing internet technology properly. Educators must provide motivation and direct students to have a more responsible attitude to use the Internet as a student's responsibility.
\end{abstract}

Keyword: Internet; Responsible; Student Guidance and Counseling

\section{Introduction}

Responsibility is the human's self-awareness of his actions. Responsibility must also come from the heart and self-will for the obligations that must be responsible. Students should learn so that what they learn can be accounted for in the form of results, and after graduating, students must be responsible for themselves. Responsibility can be considered as a target behavior, which is the output of certain behavioral coaching factors (Khaniki \& Khalili, 2017). One of the responsibilities of prospective counselors is to avoid cheating, so it is necessary to understand that cheating by utilizing technology is wrong and should be avoided (Cilliers, 2017). Prospective counselors should know that the internet is useful for finding information that is useful for their courses.

Several studies have shown that internet technology has the potential to provide a collaborative learning environment (Looi et al., 2009). Students can use the Internet to do work on academics, and students who have not used the Internet require the efforts of the university to provide internet facilities (Bashir, Mahmood, \& Shafique, 2016). Students know that it is challenging to manage the time they spend on the Internet per day because of unlimited data plans on mobile devices. Many students cannot use their time correctly in using the Internet for school, so students need to understand how to use the Internet properly (Fortson, Scotti, Chen, Malone, \& Del Ben, 2007; Zhang, Amos, \& McDowell, 2008)

Students who use the Internet intensively can exacerbate the state of negative emotions. Many students want to be directly involved in various activities on the Internet. Students who feel bored with vulnerability, impulsiveness, and temperament will look for something new that causes addictive behavior (Belcher, Volkow, Moeller, \& Ferré, 2014; Wegner \& Flisher, 2009). Research on "Internet Usage and Problematic Internet Us" has focused on personal effects while at some level ignoring the influence of predictors related to contextual and related to the activity.

Research on behavioral development, which places adolescents / adults at the top end of the "problematic Internet and Internet use" continuum, is influenced by these three areas, a more balanced emphasis on each individual, contextual, and related factors Internet factors. Future longitudinal research needs to be adopted to achieve comprehensive insights about the 
behavior of newly emerging adult / teenage girls. More effective prevention and information intervention policies can maximize the benefits of "Internet use" and minimize the negative impact of "Our Troubled Internet" on teens. The internet is widely accessible and is considered essential to inform young people about mental health issues to improve mental health and well-being and prevent mental stress (Anderson, Steen, \& Stavropoulos, 2017), so prospective advisers need it. The internet can increase access to this type of information and consequently reduce unmet needs.

The purpose of this study is to look at the responsible attitude of prospective counselors in utilizing internet technology to complete the guidance and counseling duties of college students. This research is conducted so that researchers can find solutions to problems for prospective counselors who are still not responsible for utilizing internet technology.

\section{Methods}

This research was carried out through a qualitative approach, which refers to a case study research design. Case studies can help researchers understand complex problems in a broad context. This qualitative research can help researchers understand complex issues in the general framework that occurs in a collection.

Researchers try to get detailed data about the responsible attitude of students in the use of internet technology to complete the culinary eye assignments given by the lecturer. The selection of these problems is to get essential matters relating to the responsible attitude of students in the use of internet technology that must be carried out by Guidance and Counseling students as prospective education counselors, in carrying out assignments as students.

The use of the case study was carried out by researchers to obtain various in-depth results related to the problem under study. By using this approach, researchers can dig up data from all subjects who took part in this research. Research is detailed research about one problem. Usually, researchers try to give an in-depth focus on the problem under study. In this case, study researchers used various methods in data collection, such as individual(interviews in-depth interviews), and document analysis. Researchers in this study will conduct the following research methods:

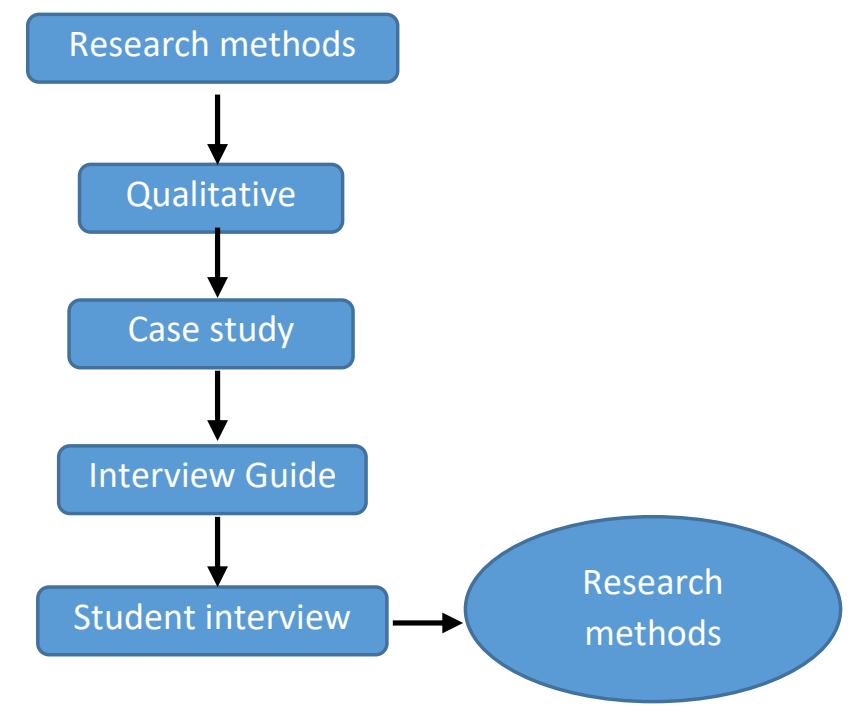

Figure 1. Method

This study involved prospective Guidance and Counseling teachers who studied at the Faculty of Tarbiyah and teacher training at UIN Raden Intan Lampung. Selection of subjects 
to be involved in a study. The stages of the subject selection, i.e. (i) choosing the initial subject which must be related to the focus of the research, (ii) choosing the advanced subject to expand the information and looking for variations that might arise from the next subject and (iii) stopping taking the subject if no more variations are found notice of the subjects interviewed. However, the selection of the initial subject becomes the main priority for obtaining information that is appropriate with this study because it may influence the smoothness in collecting the next important information. The following are interview guides that have been conducted to prospective teachers at UIN Raden Intan Lampung.

\begin{tabular}{|c|c|}
\hline Section & Questions \\
\hline Opening questions & $\begin{array}{l}\text { Pa. What do you think about the use of internet technology at the } \\
\text { moment? } \\
\text { PB What applications do you often use when you are working on } \\
\text { internet tasks? }\end{array}$ \\
\hline \multirow[t]{3}{*}{ Rate Receiving } & $\begin{array}{l}\text { 1a. What is the first thing you (friends) do when you get an assignment } \\
\text { from the lecturer? }\end{array}$ \\
\hline & $\begin{array}{l}\text { 1b. Which method or method do you often use to make it easier for } \\
\text { you to do the work of the lecturer? }\end{array}$ \\
\hline & 1c. How do you do the assignment if the source is from the internet? \\
\hline \multirow[t]{2}{*}{ Responding Level } & $\begin{array}{l}\text { 2a. What do you do if you find the same material from an assignment } \\
\text { given by a lecturer and obtained from the internet? }\end{array}$ \\
\hline & $\begin{array}{l}2 \mathrm{~b} \text {. If you get a topic that suits your assignment, will you take the } \\
\text { theory right away, or will you take the essence of the topic sentence, or } \\
\text { what? } \\
2 \mathrm{c} \text {. How do you respond in response to assignments from lecturers that } \\
\text { you get from the internet? }\end{array}$ \\
\hline \multirow[t]{2}{*}{ Valuing Level } & $\begin{array}{l}\text { 3a. Is after you get the material given you are able to fully understand } \\
\text { the theory and be able to apply it, or just to fulfill the task. }\end{array}$ \\
\hline & $\begin{array}{l}\text { 3b. What lessons can you take from the assignments you do on the } \\
\text { internet? } \\
\text { 3c. Well, do you think with the assignment given by the lecturer, } \\
\text { should we apply the theory or just as fulfilling the obligation to collect } \\
\text { assignments? }\end{array}$ \\
\hline $\begin{array}{l}\text { Organization } \\
\text { Level }\end{array}$ & $\begin{array}{l}\text { 4a. When we get opinions / understanding from lecturers and find } \\
\text { things that are different from what you read on the internet. How do } \\
\text { you respond to these differences } \\
4 \mathrm{~b} \text {. How do you carry out the process of building knowledge on the } \\
\text { basis of these differences? } \\
\text { 4c. How do you present the difference of opinion? }\end{array}$ \\
\hline $\begin{array}{l}\text { Characterization } \\
\text { level }\end{array}$ & $\begin{array}{l}5 \mathrm{c} \text {. Are there lessons that you can learn from your habit of using the } \\
\text { internet as a source for completing your assignments? }\end{array}$ \\
\hline Closing Question & $\begin{array}{l}\text { Ppa. In your view, do your friends use the internet as a source of } \\
\text { completing tasks well? }\end{array}$ \\
\hline
\end{tabular}


According to what you know, whether your friend has applied the internet to fulfill the assignments of the lecturer?

The research data were analyzed by descriptive thematically using Nvivo 10 software, which is the latest type of information developed specifically to facilitate in analyzing and organizing qualitative data. Before the interview data were analyzed using the software, all the results of the session were listened to first and transcribed one by one in the form of dialogue or verbatim. So on before the transcription results are entered into the NVivo software, all the transcription results are confirmed to be clean first.

\section{Results and Discussion}

The following results are stated by the subjects about the five components. To make it easier to understand the explanations put forward, the researcher uses the following code for all reports of the results of the research carried out. The interview results found that the use of the internet is very helpful and useful to support the learning given by lecturers. However, these uses also contain negative elements, passed away to individuals who use the application. In using the internet to help with the work, there are a number of applications commonly used by prospective teachers.

In working on assignments whose sources are from the internet, several methods are used by interviewees, some directly copy paste and read them first then paste. But there are some sources saying that they do not bother with the task when it can be desired immediately copy and paste. In addition, in the application section related to the assignment, most students work on assignments just to fulfill the lecturers' obligations only.

Furthermore, student attitudes are related to the understanding given by the lecturer and those obtained on the internet; most students can respond to it well by combining the two theories between the theory given by the lecturer, and the theory from the internet. After that, students conclude and combine the two theories. The learning that students get from the convenience of the internet is that they feel very helped; however they don't really understand what they get from the internet. Internet as a source for completing tasks well; with the internet the ease of learning is insight. However, student attitudes are still not able to apply well in students' learning and assignments. In addition, the internet becomes a source of students when students are tired of using books. Overall, it can be concluded that the internet gives a good impression to students, especially to students. However, if it is not used properly, the learning or assignments given by the lecturers have no meaning but will foster an attitude of responsibility that is lacking. In addition, students 'perceptions of lecturers' assessments are also still very alarming, this might make students feel comfortable assignments given by lecturers. In addition, students do assignments merely to get grades. The use of the internet itself students find it very helpful, most students also use the internet to fulfill their academic assignments.

The internet makes it easy for students to get assignments or material easily and quickly. Global network communication on computers that can be called the internet (internetworking) today, it seems humans who use the internet can hold the world as if (Supriyanto \& Muhsin, 2008). The internet has become one of the media in human life, especially in the world of education which provides very important benefits in the search for all information related to teaching and learning.

Internet-based e-learning is a program that supports learning. E-learning directly supports learning and teaching to be more effective. This is in line with the results of the investigation, which states that with the internet students easily find and do assignments 
given by lecturers. In addition, they can combine teacher teaching and internet results (Clark \& Mayer, 2012).

However, the internet has many positive impacts, but also negative impacts. This depends on the individual's use of the internet. One application on the internet is Facebook, which can be one of the communication media in teaching and learning. Internet technology, like Facebook, has positive and negative impacts on its users. Facebook internet technology can be used in educational contexts with several different events. Research shows that students have high scores when participating in Facebook internet technology groups (Bowman \& Akcaoglu, 2014).

Some experts find that when students understand internet technology as a learning aid, it motivates effectiveness, encourages interaction, and improves the learning process (Abas, Lim, \& Woo, 2009; Hussin, Manap, Amir, \& Krish, 2012; Ismail, Azizan, \& Azman, 2013; Jacob \& Issac, 2008; Nordin, Embi, Yasin, Rahman, \& Yunus, 2010). The results of the study are in line with the results of research conducted by researchers that the internet can help them in improving the learning process. However, their attitude towards the internet is still in the low category. it leads to the lack of attitude of student responsibility towards the assignments given by the lecturer.

Learning by using website-based media can improve student performance in learning. The internet-based learning environment influences learning positively by using the right strategy. Thus, students who get learning by utilizing internet-based learning media as a learning resource can provide learning outcomes that are different from students who get conventional learning (Kutlu \& Menzi, 2013).

Lecturers play a role as facilitators, dynamists, and motivators in the learning process. Students must find their own way to absorb the material presented by the lecturer in order to get a comprehensive understanding and broad knowledge insight. Therefore, students are required to look for as many learning resources. Learning resources can come from books, scientific journals, the internet, magazines, newspapers, television, and so on. The development of Internet network technology has changed the paradigm in getting information and communicating, which is no longer limited by the dimensions of space and time. Through the existence of the internet, they can get the information needed wherever and whenever the desired time (Adri, 2007).

Based on the results of the study, that at the State Islamic University (UIN), Raden Intan Lampung found that internet technology used by students is still widely used for personal needs, not yet fully used to assist in learning. This was shown by students from the results of interview passages, that in doing the assignments given by the lecturers, they only did copy-paste, and only checked or changed a little material obtained from the internet. Thus, the results of the semester or goal tests, they find unsatisfactory results. Students who use internet technology (for personal use) are reported to have a lower GPA (Kirschner \& Karpinski, 2010). Significant negative impact of the use of internet technology on broad student involvement (Junco, 2012).

Internet technology can foster relationships and enhance collaboration in meaningful classrooms (Mazer, Murphy, \& Simonds, 2009). Facebook can improve learning outcomes related to cognitive and affective students so as to create a more comfortable classroom atmosphere. Other research, on the other hand, shows that using Facebook internet technology as communication when outside the classroom, as well as learning aids in class, thus the technology can not only increase grades but also the involvement of students with lecture material (Bowman \& Akcaoglu 2014 ). This is hope for lecturers for BK students at UIN Raden Intan Lampung. 
Responsibility is needed by students in utilizing the internet. They can use the internet as a way to find information related to the material in lectures, so students can be more responsible for what they do in the use of the internet to find information.

\section{Conclusions and Suggestions}

Educators need to be more motivating and directing students to use the internet as a student's responsibility. The results showed that students' attitudes lacked a sense of responsibility in carrying out the mandate given by the lecturer. Thus, through this research, it is hoped that all parties involved in education can use technology appropriately.

Suggestions for further research are about providing information services to students regarding the ethical and responsible use of internet technology. Educators also need to provide services to students so that they can be more responsible in utilizing internet technology in completing their assignments.

\section{References}

Abas, Z. W., Lim, T. S. K., \& Woo, T.-K. (2009). Mobile learning initiative through SMS: A formative evaluation. ASEAN Journal of Open and Distance Learning, 1(1), 49-58.

Adri, M. (2007). Pemanfaatan Internet sebagai sumber pembelajaran. IlmuKomputer. Com.[Diakses Januari 2013].

Anderson, E. L., Steen, E., \& Stavropoulos, V. (2017). Internet use and Problematic Internet Use: A systematic review of longitudinal research trends in adolescence and emergent adulthood. International Journal of Adolescence and Youth, 22(4), 430-454.

Bashir, S., Mahmood, K., \& Shafique, F. (2016). Internet use among university students: a survey in University of the Punjab, Lahore. Pakistan Journal of Information Management \& Libraries (PJIM\&L), 9(1).

Belcher, A. M., Volkow, N. D., Moeller, F. G., \& Ferré, S. (2014). Personality traits and vulnerability or resilience to substance use disorders. Trends in Cognitive Sciences, 18(4), 211-217.

Bowman, N. D., \& Akcaoglu, M. (2014). "I see smart people!": Using Facebook to supplement cognitive and affective learning in the university mass lecture. The Internet and Higher Education, 23, 1-8.

Clark, R. C., \& Mayer, R. E. (2012). Scenario-based e-learning: Evidence-based guidelines for online workforce learning. John Wiley \& Sons.

Fortson, B. L., Scotti, J. R., Chen, Y.-C., Malone, J., \& Del Ben, K. S. (2007). Internet use, abuse, and dependence among students at a southeastern regional university. Journal of American College Health, 56(2), 137-144.

Hussin, S., Manap, M. R., Amir, Z., \& Krish, P. (2012). Mobile learning readiness among Malaysian students at higher learning institutes. Asian Social Science, 8(12), 276.

Ismail, I., Azizan, S. N., \& Azman, N. (2013). Mobile Phone as Pedagogical Tools: Are Teachers Ready?. International Education Studies, 6(3), 36-47.

Jacob, S. M., \& Issac, B. (2008). Mobile technologies and its impact-an analysis in higher education context. International Journal of Interactive Mobile Technologies, 2(1).

Junco, R. (2012). In-class multitasking and academic performance. Computers in Human Behavior, 28(6), 2236-2243. 
Kirschner, P. A., \& Karpinski, A. C. (2010). Facebook® and academic performance. Computers in Human Behavior, 26(6), 1237-1245.

Kutlu, M. O., \& Menzi, N. (2013). The Effect of Implementation of Internet-Based Teaching Model Considers Gagne's instructional Events Model in Information Technology Course for Primary (Elementary) Education to Academic Success and Retention. International Journal of Humanities and Social Science, 18(3).

Looi, C.-K., Wong, L.-H., So, H.-J., Seow, P., Toh, Y., Chen, W., ... Soloway, E. (2009). Anatomy of a mobilized lesson: Learning my way. Computers \& Education, 53(4), $1120-1132$.

Mazer, J. P., Murphy, R. E., \& Simonds, C. J. (2009). The effects of teacher self-disclosure via Facebook on teacher credibility. Learning, Media and Technology, 34(2), 175-183.

Nordin, M. N., Embi, M. A., Yasin, R. M., Rahman, S., \& Yunus, M. M. (2010). The mobile learning readiness of the post-graduate students. EABR \& ETLC Conference and Proceedings.

Supriyanto, W., \& Muhsin, A. (2008). Teknologi informasi perpustakaan. Kanisius.

Wegner, L., \& Flisher, A. J. (2009). Leisure boredom and adolescent risk behaviour: A systematic literature review. Journal of Child and Adolescent Mental Health, 21(1), 128.

Zhang, L., Amos, C., \& McDowell, W. C. (2008). A comparative study of Internet addiction between the United States and China. CyberPsychology \& Behavior, 11(6), 727-729. 
